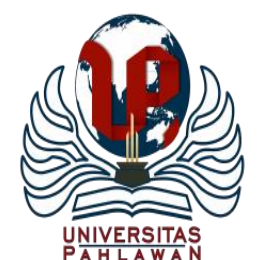

Jurnal Basicedu Volume 1 Nomor 3 Tahun 2019 Halaman 303-309

EDUKATIF: JURNAL ILMU PENDIDIKAN

Research \& Learning in Education

https://edukatif.org/index.php/edukatif/index

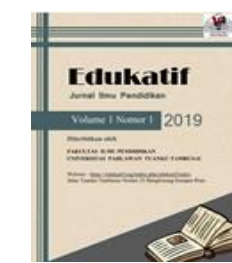

\title{
MISKONSEPSI MAHASISWA TADRIS IPA TENTANG KOMUNIKASI SEMUT BERDASARKAN AL QUR'AN
}

\author{
Eka Putra ${ }^{1}$, Rian Vebrianto ${ }^{2}$ \\ Universitas Islam Negeri Sultan Syarif Kasim Riau ${ }^{1}$, Universitas Islam Negeri Sultan Syarif Kasim Riau ${ }^{3}$ \\ e-mail : Onga.eka.putra@gmail.com ${ }^{1}$, rian.vebrianto@uin-suska.ac.id ${ }^{2}$
}

\begin{abstract}
Abstrak
Penelitian ini bertujuan untuk mengetahui miskonsepsi mahasiswa tadris IPA UIN Sultan Syarif Kasim tentang komunikasi semut dalam perspektif Al-Qur'an. Jenis penelitian yang digunakan dalam penelitian ini adalah penelitian survey. Dalam penelitian ini, yang dijadikan subjek penelitian adalah 30 Mahasiswa tadris IPA semester IV UIN Sultan Syarif Kasim. Teknik pengumpulan data dalam penelitian ini adalah angket dengan menggunakan skala likert. Analisis data yang dilakukan adalah reduksi data, penyajian data, dan menarik kesimpulan. Berdasarkan paparan yang peneliti uraikan pada pembahasan maka dapat dilihat bahwa dari 15 pernyataan yang terdapat pada angket yang telah disebarkan kepada mahasiswa tadris IPA UIN Sultan Syarif Kasim hanya satu angket saja miskonsepsi yang dialami oleh mahasiswa, yaitu pada pernyatan 4 . Berdasarkan hal tersebut, dapat disimpulkan bahwa Mahasiswa tadris IPA UIN Sultan Syarif Kasim tidak mengalami miskonsepsi tentang komunikasi semut dalam perspekif Al-Qur'an.
\end{abstract}

Kata Kunci: miskonsepsi, mahasiswa tadris ipa, komunikasi semut

\begin{abstract}
This study aims to find out the misconception of the students of Tadris IPA UIN Sultan Syarif Kasim about ant communication in the perspective of the Qur'an. The type of research used in this research is survey research. In this study, the subjects of the study were 30 students of Sultan Syarif Kasim's UIN semester IV Science Faculty. Data collection techniques in this study were questionnaires using a Likert scale. Data analysis carried out was data reduction, data presentation, and drawing conclusions. Based on the explanation that the researcher described in the discussion, it can be seen that from the 15 statements contained in the questionnaire that had been disseminated to the students of Islamic Science UIN, Sultan Syarif Kasim, only one questionnaire was misconceptions experienced by students, namely in statement 4. Based on this, it can be concluded that the Student of the IPA Tadris Sultan Syarif Kasim did not experience misconceptions about ant communication in the perspective of the Qur'an.
\end{abstract}

Keywords: misconception, student tadris ipa, ant communication

@Edukasi: Jurnal Ilmu Pendidikan FIP UPTT 2019

$\triangle$ Corresponding author :

Address : Alamat penulis

Email : Email Penulis

Phone : -
ISSN 2656-8071 (Media Cetak)

ISSN 2656-8063 (Media Online) 


\section{PENDAHULUAN}

Semut adalah makhluk hidup dengan populasi terpadat di dunia. Perbandingannya, untuk setiap 700 juta semut yang muncul ke dunia ini, hanya terdapat 40 kelahiran manusia. Semut merupakan salah satu kelompok yang paling "sosial" dalam genus serangga dan berasal dari keluarga Formicidae, semut termasuk dalam ordo Hymenoptera bersama dengan lebah dan tawon. Semut terbagi atas lebih dari 12.000 kelompok, dengan perbandingan jumlah yang besar di kawasan tropis. Semut dikenal dengan koloni dan sarang-sarangnya yang teratur, yang terkadang terdiri dari ribuan semut per koloni. Jenis semut dibagi menjadi semut pekerja, semut prajurit, semut pejantan, dan ratu semut (Bert HolldoblerEdward O. Wilson,1990). Di kerajaan semut ini, yang menjadi pemimpin adalah semut betina dan bukan semut jantan. Karenanya mereka hanya memiliki ratu, dan tidak memiliki raja. Adapun sebabnya dikarenakan bentuk tubuh sang ratu yang besar dan peranan penting yang dimainkannya. Para betina memiliki tugas antara lain; mendidik, menjaga dan mengawasi pertumbuhan anakanaknya, menyiapkan danmenyimpan persedian makanan. Adapun jantannya, hanya bertugas untuk mempertahankan dan membela kehidupan mereka. Untuk itu, mereka akan mendapatkan imbalan dengan dipenuhinya semua kebutuhan pokok mereka tanpa harus berpayah-payah bekerja. Semua ini berjalan berdasarkan perintah dari ratu dan para pembantunya.

Interaksi yang terjadi antara sesama semut membutuhkan suatu media komunikasi. Semut mempunyai 'bahasa khusus' yang mereka gunakan untuk saling berkomunikasi di antara sesama mereka, sehingga kehidupan mereka bisa berjalan secara teratur dan tertib. Penelitian ilmiah tentang semut pada abad ini menunjukkan adanya jaringan kom unikasi yang luar biasa di antara makhluk ini (Saleh,2011).
Pada kepala semut terdapat banyak organ sensor. Semut, layaknya serangga lainnya, memiliki mata majemuk yang terdiri dari kumpulan lensa mata yang lebih kecil dan tergabung untuk mendeteksi gerakan dengan sangat baik. Kebanyakan semut umumnya memiliki penglihatan yang buruk, bahkan beberapa jenis dari mereka buta. Namun, beberapa spesies semut, semisal semut bulldog Australia, memiliki penglihatan yang baik. Pada kepalanya juga terdapat sepasang antena yang membantu semut mendeteksi rangsangan kimiawi. Antena semut juga digunakan untuk berkomunikasi satu sama lain dan mendeteksi feromon yang dikeluarkan oleh semut lain. Selain itu, antena semut juga berguna sebagai alat peraba untuk mendeteksi segala sesuatu yang berada di depannya. Pada bagian depan kepala semut juga terdapat sepasang rahang atau mandibula yang digunakan untuk membawa makanan, memanipulasi objek, membangun sarang, dan untuk pertahanan. Pada beberapa spesies, di bagian dalam mulutnya terdapat semacam kantung kecil untuk menyimpan makanan untuk sementara waktu sebelum dipindahkan ke semut lain atau larvanya ((McIntyre et al. 2001; Smith et al. 2006).

Saat menjelajahi dunia semut yang istimewa ini, kita akan dibuat terkagum-kagum oleh sistem yang sempurna ini dan semakin merasa perlu untuk berpikir dan menyelidiki. Dalam Al Quran, mereka yang berpikir tentang alam sehingga mengenali kemahakuasaan Allah, dipuji sebagai teladan bagi orang beriman. Ayatayat berikut menjelaskan hal ini secara lengkap:

Sesungguhnya dalam penciptaan langit dan bumi dan silih bergantinya malam dan siang, terdapat tanda-tanda bagi orang-orang yang berakal, (yaitu) orang-orang yang mengingat Allah sambil berdiri atau duduk atau dalam keadaan berbaring, dan mereka memikirkan penciptaan langit dan bumi (seraya berkata): "Ya Tuhan kami, tiadalah Engkau menciptakan ini 
dengan sia-sia. Maha Suci Engkau. Maka, peliharalah kami dari siksa neraka”. (Surat Al 'Imran: 190-191). Komunikasi semut sebenarnya telah dipelajari pada jenjang SMA sebelumnya merupakan prasyarat untuk mempelajari konsep komunikasi semut di bangku kuliah sehingga tidak terjadi miskonsepsi. Menurut Brown (Suparno, 2005:4) miskonsepsi merupakan penjelasan yang salah dan suatu gagasan yang tidak sesuai dengan pengertian ilmiah yang diterima para ahli. Lebih lanjut Ibrahim (Ibrahim, 2012) menyatakan bahwa miskonsepsi adalah kesalahan konsep yang terjadi akibat seseorang yang tetap kembali ke konsep awal yang dimilikinya padahal orang tersebut telah diperkenalkan pada konsep yang benar.

Suparno memandang miskonsepsi sebagai pengertian yang tidak akurat akan konsep, penggunaan konsep yang salah, klasifikasi contohcontoh yang salah, kekacauan konsep-konsep yang berbeda, dan hubungan hirarkis konsep-konsep yang tidak benar (Suparno, 2005). Sejalan dengan Suparno, Zaidatul Malikha dan Mohammad Faizal Amir mendefenisikan miskonsepsi lebih mendetail, yaitu pemahaman yang tidak akurat akan konsep, penggunaan konsep yang tidak sesuai dengan konsep yang telah disepakati secara ilmiah oleh pakar ahli dalam bidang tersebut, ketidak mampuan dalam menghubungkan konsep awal dengan konsep selanjutnya secara benar dan bersifat resisten atau sulit diubah (Amir, 2018). Dari beberapa pengertian diatas dapat disimpulkan bahwa miskonsepsi adalah kesalahan konsep, penggunaan konsep yang tidak sesuai dengan konsep yang telah disepakati secara ilmiah oleh pakar ahli dalam bidang tersebut, ketidak mampuan dalam menghubungkan konsep awal dengan konsep selanjutnya secara benar dan kembalinya seseorang ke konsep awal yang dimilikinya sekalipun telah diperkenalkan pada konsep yang benar.

Berdasarkan hasil wawancara yang peneliti lakukan dengna beberapa mahasiswa tadris IPA di
UIN SUSKA mengenai komunikasi semut dalam perspektif Al Qur'an, dar 10 mahasiswa hanya 2 mahasiswa yang tahu bahwa komunikasi semut terdapat dalam Al Qur'an. berdasarkan masalah tersebut, peneliti mencoba meneliti tentang Profil Miskonsepsi Mahasiswa Tadris IPA tentang Komunikasi Semut dalam Perspektif Al Qur'an.

\section{METODE PENELITIAN}

Jenis penelitian yang digunakan dalam penelitian ini adalah penelitian survey. Dalam penelitian ini, yang dijadikan subjek penelitian adalah 30 Mahasiswa tadris IPA semester IV UIN Sultan Syarif Kasim. Teknik pengumpulan data dalam penelitian ini adalah angket dengan menggunakan skala likert. Analisis data yang dilakukan adalah reduksi data, penyajian data, dan menarik kesimpulan. Reduksi data dilakukan, setelah angket di uji coba kepada mahasiswa. Untuk mengetahui mahasiswa yang mengalami miskonsepsi, maka dilihat dari nilai rata-rata per angket yang telah di isi mahasiswa. Selanjutnya penyajian data yang bertujuan untuk memudahkan peneliti dan pembaca dalam memahami apa yang terjadi. Penyajian data pada penelitian ini menggunakan teks yang bersifat naratif dengan bantuan gambar hasil analisis yang di buat di SPSS. Setelah mendisplay data maka langkah selanjutnya adalah menarik kesimpulan dari pembahasan yang dipaparkan.

\section{HASIL DAN PEMBAHASAN PENELITIAN}

Adapun angket yang disebarkan sebanyak 30 angket dengan 15 pernyataan. Dimana angket tersebut berisi pernyataan positif yaitu pernyataan $1,2,3,5,6,7,8,10,11,13$, dan 15 dan pernyataan negatif yaitu pernyataan 4, 9, 12, dan 14. Adapun hasil angket yang telah di isi oleh responden mengenai komunikasi semut dalam perspektif $\mathrm{Al}-$ Qur'an di uraikan berdasarkan pernyataan positif dan negatif, di bawah ini: 
Tabel 1. Frekuensi, dan rata-rat dari pernyataan Positif

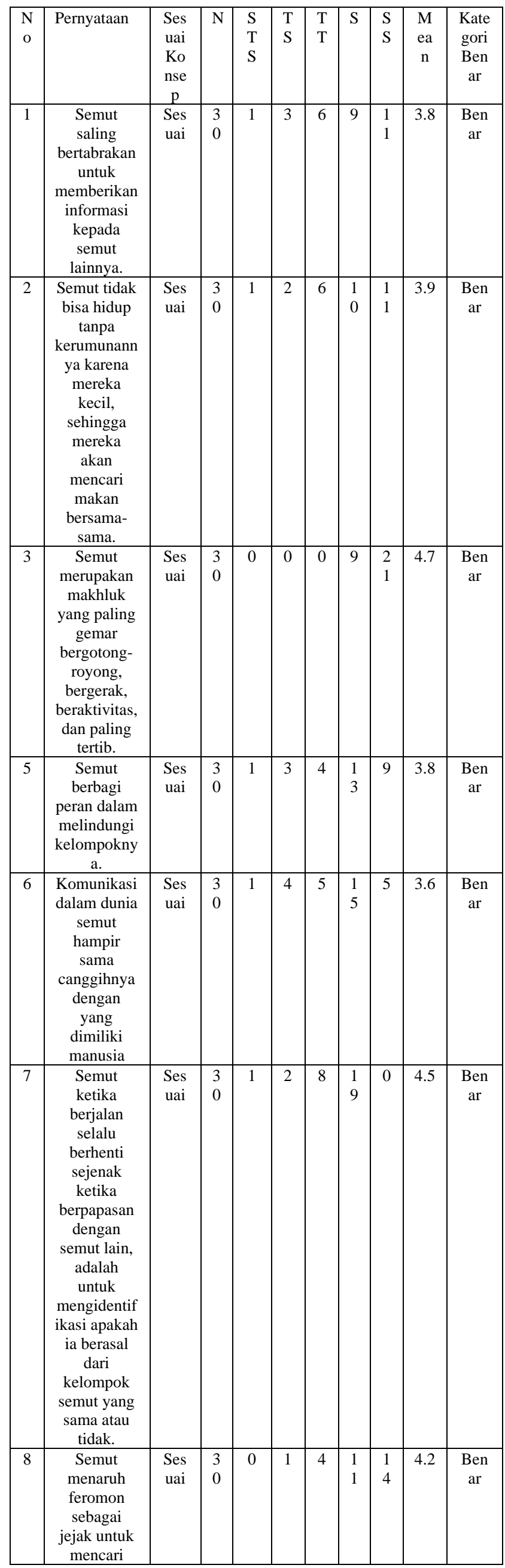

\begin{tabular}{|c|c|c|c|c|c|c|c|c|c|c|}
\hline & $\begin{array}{c}\text { sumber } \\
\text { makanan. }\end{array}$ & & & & & & & & & \\
\hline $\begin{array}{l}1 \\
1\end{array}$ & $\begin{array}{c}\text { Semut } \\
\text { merupakan } \\
\text { makhluk } \\
\text { yang } \\
\text { berjiwa } \\
\text { sosial } \\
\text { tinggi. }\end{array}$ & $\begin{array}{l}\text { Ses } \\
\text { uai }\end{array}$ & $\begin{array}{l}3 \\
0\end{array}$ & 1 & 2 & 4 & $\begin{array}{l}1 \\
3\end{array}$ & $\begin{array}{l}1 \\
0\end{array}$ & 4.4 & $\begin{array}{c}\text { Ben } \\
\text { ar }\end{array}$ \\
\hline $\begin{array}{l}1 \\
3\end{array}$ & $\begin{array}{c}\text { Semut } \\
\text { umumnya } \\
\text { memiliki } \\
\text { penglihatan } \\
\text { yang buruk. }\end{array}$ & $\begin{array}{l}\text { Ses } \\
\text { uai }\end{array}$ & $\begin{array}{l}3 \\
0\end{array}$ & 2 & 2 & 2 & $\begin{array}{l}1 \\
2\end{array}$ & $\begin{array}{l}1 \\
2\end{array}$ & 3.9 & $\begin{array}{c}\text { Ben } \\
\text { ar }\end{array}$ \\
\hline $\begin{array}{l}1 \\
5\end{array}$ & $\begin{array}{c}\text { Semut } \\
\text { berkomunik } \\
\text { asi } \\
\text { menggunak } \\
\text { an } \\
\text { antenanya }\end{array}$ & $\begin{array}{l}\text { Ses } \\
\text { uai }\end{array}$ & $\begin{array}{l}3 \\
0\end{array}$ & 1 & 1 & 2 & $\begin{array}{l}1 \\
2\end{array}$ & 4 & 4.2 & $\begin{array}{c}\text { Ben } \\
\text { ar }\end{array}$ \\
\hline
\end{tabular}

Berdasarkan tabel 1, dapat dilihat bahwa untuk pernyataan 1,2 , dan 3 dimana pernyataan tersebut berisi penyataan positif yaitu Semut saling bertabrakan untuk memberikan informasi kepada semut lainnya, Semut tidak bisa hidup tanpa kerumunannya karena mereka kecil, sehingga mereka akan mencari makan bersama-sama, dan Semut merupakan makhluk yang paling gemar bergotong-royong, bergerak, beraktivitas, dan paling tertib. Pada pernyataan 1 , mahasiswa yang memilih SS sebanyak 11 orang, S sebanyak 9 orang, TT sebanyak 6 orang, TS sebanyak 3 orang, dan STS sebanyak 1 orang. Pernyatan 2, mahasiswa yang memilih SS sebanyak 11 orang, S sebanyak 10 orang, TT sebanyak 6 orang, TS sebanyak 2 orang, dan STS sebanyak 1 orang. Rata-rata rseponden setuju dengan pernyataan 1,2 , dan 3 dengan nilai rata-rata masing-masing angket 3.8, 3.9, dan 4.7. hal ini sejalan dengan penelitian yang dilakukan oleh Siti Fatihatul Ulfa (2018) menyebutkan bahwa Semut tidak bisa hidup tanpa kerumunannya karena mereka kecil, sehingga mereka akan mencari makan bersama-sama, dan Semut merupakan makhluk yang paling gemar bergotong-royong, bergerak, beraktivitas, dan paling tertib. Berdasarkan paparan tersebut, pada pernyataan 1, 2, dan 3 mahasiswa tidak mengalami miskonsepsi.

Berdasarkan tabel 1, dapat dilihat bahwa untuk pernyataan 5,6, dan 7 dimana pernyataan 
tersebut berisi penyataan positif yaitu Semut berbagi peran dalam melindungi kelompoknya, Komunikasi dalam dunia semut hampir sama canggihnya dengan yang dimiliki manusia, sehingga mereka akan mencari makan bersamasama, dan Semut ketika berjalan selalu berhenti sejenak ketika berpapasan dengan semut lain, adalah untuk mengidentifikasi apakah ia berasal dari kelompok semut yang sama atau tidak. Pernyataan 5, mahasiswa yang memilih SS sebanyak 9 orang, S sebanyak 13 orang, TT sebanyak 4 orang, TS sebanyak 3 orang, dan STS sebanyak 1 orang. Pernyataan 6, mahasiswa yang memilih SS sebanyak 5 orang, S sebanyak 15 orang, TT sebanyak 5 orang, TS sebanyak 4 orang, dan STS sebanyak 1 orang. Pernyataan 7, mahasiswa yang memilih SS sebanyak 0orang, S sebanyak 19 orang, TT sebanyak 8 orang, TS sebanyak 2 orang, dan STS sebanyak 1 orang. Rata-rata rseponden setuju dengan pernyataan 5,6, dan 7 dengan nilai rata-rata masing-masing angket 3.8, 3.6, dan 4.5. Hal ini sejalan dengan penelitian yang dilakukan oleh Hasriyanty menyebutkan bahwa Ketika dua semut bertabrakan atau saling berpapasan, mereka akan mendekatkan kepala mereka satu sama lain untuk memastikan mereka termasuk dalam koloni yang sama atau tidak. Nah, jika tidak, keadaannya akan berbeda. Semut memiliki penciuman yang baik, karena itu mereka sangat baik dalam mendeteksi penyusup. Jika berpapasan dengan semut dari koloni yang berbeda, keduanya akan segera mundur dan segera menyelamat diri. Berdasarkan paparan tersebut, pada pernyataan 5,6 , dan 7 mahasiswa tidak mengalami miskonsepsi

Rata-rata dan persentase dari pernyataan 8,10 , dan 11 dimana pernyataan tersebut berisi penyataan positif yaitu Semut menaruh feromon sebagai jejak untuk mencari sumber makanan, Semut merupakan makhluk yang berjiwa sosial tinggi, dan Walaupun semut dikatakan mampu mengangkat beban 2 kali berat tubuhnya. Namun mereka tidak bisa bekerja sendiri. Pada pernyataan 8, mahasiswa yang memilih SS sebanyak 14 orang, S sebanyak 11 orang, TT sebanyak 4 orang, TS sebanyak 1 orang, dan STS tidak ada yang memilih. Pernyatan 10, mahasiswa yang memilih SS sebanyak 12 orang, S sebanyak 14 orang, TT sebanyak 2 orang, TS sebanyak 1 orang, dan STS sebanyak 1 orang. Pernyataan 11, mahasiswa yang memilih SS sebanyak 10 orang, S sebanyak 13 orang, TT sebanyak 4 orang, TS sebanyak 2 orang, dan STS sebanyak 1 orang Rata-rata rseponden setuju dengan pernyataan 8,10 , dan 11 dengan nilai rata-rata masing-masing angket 4.2, 4.4, dan 3.9. Hal ini sejalan dengan penelitian yang dilakukan oleh Arif Kurniawan (2014) menyebutkan bahwa Semut menaruh feromon sebagai jejak untuk mencari sumber makanan, Semut merupakan makhluk yang berjiwa sosial tinggi, dan Walaupun semut dikatakan mampu mengangkat beban 2 kali berat tubuhnya. Berdasarkan paparan tersebut, pada pernyataan 8,10 , dan 11 mahasiswa tidak mengalami miskonsepsi.

Frekuansi, rata-rata dan persentase dari pernyataan 13 dan 15 dimana pernyataan tersebut berisi penyataan positif yaitu Semut umumnya memiliki penglihatan yang buruk dan Semut berkomunikasi menggunakan antenanya. Pernyatan 13, mahasiswa yang memilih SS sebanyak 12 orang, S sebanyak 12 orang, TT sebanyak 2 orang, TS sebanyak 2 orang, dan STS sebanyak 2 orang. Pernyataan 15, mahasiswa yang memilih SS sebanyak 12 orang, S sebanyak 14 orang, TT sebanyak 2 orang, TS sebanyak 1 orang, dan STS sebanyak 1 orang. Rata-rata rseponden setuju dengan pernyataan 13 dan 15 dengan nilai rata-rata masing-masing angket 4.0 dan 4.2. Hal ini sejalan dengan penelitian yang dilakukan oleh Muhtadin (2011) menyebutkan bahwa Semut umumnya memiliki penglihatan yang buruk dan Semut berkomunikasi menggunakan antenanya. 
Berdasarkan paparan tersebut, pada pernyataan 13 dan 15 mahasiswa tidak mengalami miskonsepsi.

Tabel 2. Frekuensi dan rata-rata dari pernyataan Negatif

\begin{tabular}{|c|c|c|c|c|c|c|c|c|c|c|}
\hline $\begin{array}{l}\mathrm{N} \\
\mathrm{o}\end{array}$ & $\begin{array}{c}\text { Pernyata } \\
\text { an }\end{array}$ & $\begin{array}{c}\text { Sesu } \\
\text { ai } \\
\text { Kon } \\
\text { sep }\end{array}$ & $\mathrm{N}$ & $\begin{array}{l}\mathrm{S} \\
\mathrm{T} \\
\mathrm{S}\end{array}$ & $\begin{array}{l}\mathrm{T} \\
\mathrm{S}\end{array}$ & $\begin{array}{l}\mathrm{T} \\
\mathrm{T}\end{array}$ & $S$ & $\begin{array}{l}S \\
S\end{array}$ & $\begin{array}{l}\mathrm{Me} \\
\text { an }\end{array}$ & $\begin{array}{l}\text { Kate } \\
\text { gori } \\
\text { salah }\end{array}$ \\
\hline 4 & $\begin{array}{c}\text { Semut } \\
\text { merupak } \\
\text { an } \\
\text { hewan } \\
\text { yang } \\
\text { bersifat } \\
\text { individu } \\
\text { al. }\end{array}$ & $\begin{array}{c}\text { Tida } \\
\mathrm{k} \\
\text { sesu } \\
\text { ai }\end{array}$ & $\begin{array}{l}3 \\
0\end{array}$ & 1 & 4 & 2 & $\begin{array}{l}1 \\
1\end{array}$ & $\begin{array}{l}1 \\
2\end{array}$ & 2.0 & Salah \\
\hline 9 & $\begin{array}{c}\text { Ketika } \\
\text { semut } \\
\text { menemu } \\
\text { kan } \\
\text { makana } \\
\text { n baik } \\
\text { dalam } \\
\text { jumlah } \\
\text { besar } \\
\text { ataupun } \\
\text { kecil, } \\
\text { semut } \\
\text { langsun } \\
\text { g } \\
\text { memaka } \\
\text { nnya. }\end{array}$ & $\begin{array}{c}\text { Tida } \\
\mathrm{k} \\
\text { sesu } \\
\text { ai }\end{array}$ & $\begin{array}{l}3 \\
0\end{array}$ & 13 & $\begin{array}{l}1 \\
5\end{array}$ & 0 & 1 & 1 & 4.3 & Salah \\
\hline $\begin{array}{l}1 \\
2\end{array}$ & $\begin{array}{c}\text { Komunit } \\
\text { as semut } \\
\text { dipimpi } \\
\text { n oleh } \\
\text { seekor } \\
\text { semut } \\
\text { yaitu } \\
\text { raja } \\
\text { semut. }\end{array}$ & $\begin{array}{c}\text { Tida } \\
\mathrm{k} \\
\text { sesu } \\
\text { ai }\end{array}$ & $\begin{array}{l}3 \\
0\end{array}$ & 1 & 1 & 2 & $\begin{array}{l}1 \\
4\end{array}$ & $\begin{array}{l}1 \\
2\end{array}$ & 4.1 & Salah \\
\hline $\begin{array}{l}1 \\
4\end{array}$ & $\begin{array}{c}\text { Semut } \\
\text { merupak } \\
\text { an } \\
\text { makhluk } \\
\text { hidup } \\
\text { dengan } \\
\text { populasi } \\
\text { paling } \\
\text { sedikit } \\
\text { di dunia. }\end{array}$ & $\begin{array}{c}\text { Tida } \\
\mathrm{k} \\
\text { sesu } \\
\text { ai }\end{array}$ & $\begin{array}{l}3 \\
0\end{array}$ & 1 & 1 & 2 & $\begin{array}{l}1 \\
2\end{array}$ & $\begin{array}{l}1 \\
4\end{array}$ & 4.2 & Salah \\
\hline
\end{tabular}

Tabel 2 merupakan frekuensi dan rata-rata dari pernyataan 4 dan 9 dimana pernyataan tersebut berisi penyataan negatif yaitu Semut merupakan hewan yang bersifat individual dan Ketika semut menemukan makanan baik dalam jumlah besar ataupun kecil, semut langsung memakannya. Rata-rata rseponden setuju dengan pernyataan 4 dan 9 dengan nilai rata-rata masingmasing angket 2.0 dan 4.3 Rata-rata pernyataan 4 berada pada kategori mahasiswa setuju dengan pernyataan 4. Padahal jika dilihat pernyataan tersebut adalah sesuatu yeng bertentangan dengan sifat asli semut. Hal ini sejalan dengan penelitian yang dilakukan oleh Ahmad Saleh (2012). Pada pernyataan 4 ini dapat dikategorikan mahasiswa mengalami miskonsepsi. Nurhamdiah (2019) menyatakan bahwa miskonsepsi adalah kesalahan konsep, penggunaan konsep yang tidak sesuai dengan konsep yang telah disepakati secara ilmiah oleh pakar ahli dalam bidang tersebut, ketidak mampuan dalam menghubungkan konsep awal dengan konsep selanjutnya secara benar dan kembalinya seseorang ke konsep awal yang dimilikinya sekalipun telah diperkenalkan pada konsep yang benar.

Frekuensi dan rata-rata dari pernyataan 12 dan 14 dimana pernyataan $\mathrm{t}$ berisi penyataan negatif yaitu Komunitas semut tidak dipimpin oleh seekor semut yaitu raja semut dan Semut merupakan makhluk hidup dengan populasi paling sedikit di dunia. Pada pernyataan 12 mahasiswa yang memilih SS sebanyak 12 orang, S sebanyak 14 orang, TT sebanyak 2 orang, TS sebanyak 1 orang, dan STS sebanyak 1 orang. Sedangkan pada pernyataan 14 mahasiswa yang memilih SS sebanyak 14 orang, S sebanyak 12 orang, TT sebanyak 2 orang, TS sebanyak 1 orang, dan STS sebanyak 1 orang . Rata-rata rseponden tidak setuju dengan pernyataan 12 dan 14 dengan nilai rata-rata masing-masing angket 4.1 dan 4.2. Hal ini sejalan dengan surah $\mathrm{An}-\mathrm{Naml}$ ayat 8 yang artinya "Hingga apabila mereka sampai di lembah semut berkatalah seekor semut: Hai semut-semut, masuklah ke dalam sarang-sarangmu, agar kamu tidak diinjak oleh Sulaiman dan tentaranya, sedangkan mereka tidak menyadari". Berdasarkan paparan tersebut, pada pernyataan 12 dan 14 mahasiswa tidak mengalami miskonsepsi. 


\section{UCAPAN TERIMA KASIH}

Terimakasih peneliti sampaikan kepada dosen pembimbing yang telah membimbing penyelesaian penelitian ini, dan juga terimaksih kepada mahasiswa tadris IPA UIN Sultan Syarif Kasim yang dalam penenelitian ini bertindak sebagai subjek penelitian.

\section{KESIMPULAN}

Berdasarkan paparan yang peneliti uraikan pada pembahasan maka dapat dilihat bahwa dari 15 pernyataan yang terdapat pada angket yang telah disebarkan kepada mahsiswa tadris IPA UIN Sultan Syarif Kasim Riau hanya satu angket saja miskonsepsi yang dialami oleh mahasiswa, yaitu pada pernyatan 4. Berdasarkan hal tersebut, dapat disimpulkan bahwa Mahasiswa tadris IPA UIN Sultan Syarif Kasim Riau tidak mengalami miskonsepsi tentang komunikasi semut dalam perspekif Al-Qur'an.

\section{DAFTAR PUSTAKA}

Ahmad Saleh, 2012. Studi berbagai jenis sarang permanen untuk mengembangbiakkan semut hitam, Dolichoderus thoracicus (Smith) (Hymenoptera: Formicidae), Jurnal Entomologi Indonesia Indonesian Journal of Entomology ISSN: 1829-7722, September 2012, Vol. 9 No. 2, 64-70 Online version: http://jurnal.pei-pusat.org

DOI: 10.5994/jei.9.2.64.

Bert Holldobler-Edward O. Wilson, 1990. The Ants, Harvard University Press.

Hasriyanty, 2013. Keanekaragaman semut dan pola keberadaannya pada daerah urban di Palu, Sulawesi Tengah, Jurnal Entomologi Indonesia Indonesian Journal of Entomology ISSN: 1829-7722, Maret 2015, Vol. 12 No.1, 39-47 Online version: http://jurnal.pei-pusat.org DOI: 10.5994/jei. 12.1.39.

Kurniawan, Aris. 2017. Keanekaragaman Semut (Subfamili: Myrmicinae) di Uin Raden Intan Lampung dan Kehidupan Sosial Semut serta
Kajianya di dalam Al-Qur'an. http://repository.radenintan.ac.id/997/1/SKR IPSI_FIX_123.pdf. Di akses di Pekanbaru tanggal 4 April 2019.

McIntyre NE, Rango J, Fagan WF, Faeth SH. 2001. Ground arthropod community structure in a heterogeneous urban environment. Landscape Urban Planning 52:257-274.

Nurhamdiah. 2019. Profil Miskonsepsi Siswa Pada Materi Pecahan Berdasarkan Tingkat Kognitif Siswa, EKSAKTA : Jurnal Penelitian dan Pembelajaran MIPA Volume 4 Nomor 1 Tahun 2019

Saleh A, Abu Hassan A. 2001. The control of cocoa pod borer (Conopomorpha cramerella) and cocoa mirid (Helopeltis theobromae) by using insecticide and black ant in Lonsum Estates, North Sumatera, Indonesia. In: The 4th Asia Pacific Conference of Entomology (Kuala Lumpur, 14-17 August 2001). pp. 4. Kuala Lumpur: Malaysian Plant Protection Society and Entomological Society of Malaysia.

Suparno, Paul. 2005. Miskonsepsi \& Perubahan Konsep Pendidikan Fisika. Jakarta : Penerbit Grasindo.

Yahya, Harun. 2003. Keajaiban pada Semut. Bandung: Dzikra. 